\title{
Descriptive study of apical periodontitis detected in Cone Beam Computed Tomography scans
}

\author{
Estudo descritivo de periodontite periapical detectada em exames de Tomografia Computadorizada de \\ Feixe Cônico
}

Lucieni Cristina Trovati MORETI

Francine Kühl PANZARELLA'

Marine de OLIVEIRA'

José Luiz Cintra JUNQUEIRA ${ }^{1}$

Luiz Roberto MANHÃES JÚNIOR ${ }^{1}$

\section{ABSTRACT}

\section{Objective}

To perform a descriptive study in order to evaluate apical periodontitis in endodontically treated teeth using cone beam computed tomography.

\section{Methods}

Eighty-six exams presenting at least one apical periodontitis were selected and divided into two groups: 1 for the mandible and 2 for the maxilla. All the exams were done using the same cone beam computed tomography with standard acquisition settings. All the images were processed and manipulated using the same software. Then the lesions were classified according to the periapical index, but not considering the expansion and/or destruction of cortical.

\section{Results}

127 mandibular teeth and 180 maxillary teeth exhibited apical periodontitis with an average size of $0.49 \mathrm{~mm}$ in the mandible and $0.75 \mathrm{~mm}$ in the maxilla. It was found that the lower pre-molars were the teeth most affected. Lesions identified with scores between 0 and 1 correspond to $83.47 \%$ of the lesions in the mandible and $78.89 \%$ in the maxilla, and $55.12 \%$ of endodontically treated lower teeth and $50 \%$ of upper teeth presented no lesion recurrence or lesions under repair.

\section{Conclusion}

There was a predominance of small apical periodontitis, the pre-molars being the teeth most affected.

Indexing terms: Apical periodontitis. Cone beam computed tomography. Diagnostic imaging. Periapical tissue.

\section{RESUMO}

Objetivo

Realizar um estudo descritivo para avaliar periodontites periapicais em dentes com tratamento endodôntico em tomografia computadorizada de feixe cônico.

\section{Métodos}

Oitenta e seis exames que apresentaram pelo menos uma periodontite periapical foram selecionados e separados em dois grupos: 1 para a mandíbula, e 2 para a maxila. Todos os exames foram realizados na tomografia computadorizada de feixe cônico com os mesmos protocolos de aquisição, e o mesmo software de avaliação e de mensuração. As lesões foram classificadas de acordo com o índice periapical, mas sem considerar a expansão do osso cortical e/ou destruição.

\section{Resultados}

Cento e vinte sete dentes inferiores e 180 dentes superiores apresentaram periodontites periapicais com tamanho médio de 0,49 mm na mandíbula e de $0,75 \mathrm{~mm}$ na maxila. Observou-se que os pré-molares inferiores foram os dentes mais acometidos. Lesões identificadas entre os escores 0 e 1 corresponderam a $83,47 \%$ das lesões na mandíbula e $78,89 \%$ na maxila, sendo que $55,12 \%$ dos dentes tratados endodonticamente inferiores e $50 \%$ superiores não apresentaram lesões reincidentes ou em fase de reparação.

\section{Conclusão}

Houve um predomínio de periodontites periapicais pequenas, sendo os pré-molares os dentes mais acometidos por estas lesões.

Termos de indexação: Periodontite periapical. Tomografia computadorizada de feixe cônico. Diagnóstico por imagem. Tecido periapical.

\footnotetext{
${ }^{1}$ Faculdade São Leopoldo Mandic, Curso de Odontologia, Programa de Pós-Graduação em Radiologia. Rua José Rocha Junqueira, 13, Swift, 13045-
} 755, Campinas, SP, Brasil. Correspondência para / Correspondence to: FK PANZARELLA. E-mail: <francinekp@hotmail.com> 


\section{INTRODUCTION}

Chronic inflammation of the periapical tissue usually develops without the patient reporting any symptoms, so the acquisition of images is fundamental to its detection ${ }^{1}$. According to several studies, the probability of apical periodontitis existing and not being identified by periapical or panoramic radiography, is considerable ${ }^{2-4}$. On the other hand, cone beam computed tomography ( $C B C T)$ images are high resolution ${ }^{1,3,5}$, permitting a more precise identification of the apical periodontitis (AP), providing more effective information about the size and location, since the superimposition of the neighboring anatomical structures ${ }^{1-4,6-15}$ is eliminated.

Studies conducted in recent years using different methodologies have reported the high sensitivity of $\mathrm{CBCT}$ in the diagnosis of $\mathrm{AP}^{1-2,4,7-17}$ and in the monitoring of the healing process. However, there have been very few publications reporting on the prevalence $^{18}$ and characteristics of AP identified in $\mathrm{CBCT}$ exams.

As far as the healing of the bone is concerned, this is deemed to be complete in $80 \%$ of treated teeth ${ }^{19}$, and it is known that the process of bone generation progresses slowly and may take four years or more to reach its conclusion. As a result, the early assessment of a periapical cure is frequently inconclusive, demanding a long period of monitoring to determine the definitive outcome of the treatment, with clinical and radiography exams being recommended ${ }^{20-22}$. Those cases confirmed as healthy in radiographs, but which reveal apical periodontitis in the CBCT and the histological examination ${ }^{4,23}$ could, for example, adversely affect the installation of immediate implants in locations where it is intended to replace a tooth suspected of having a possible endodontic pathology?.

A number of studies ${ }^{24-26}$ have used the Periapical Index (PAI) system, the frame of reference for the various stages of apical periodontitis. Estrela et al. ${ }^{27}$ developed a periapical index called the CBCT-PAl, which is based on the criterion established through measurements corresponding to the periapical radio-translucence interpreted in CBCT exams, in other words in 3D.

The aim of the present study is to describe the characteristics of instances of apical periodontitis viewed in CBCT exams using the periapical index proposed by Estrela et al. ${ }^{27}$.

\section{METHODS}

Following approval by the Research Ethics Committee at the São Leopoldo Mandic Dental Research Center, under record no. 2010/0025, a total of 250 computed tomography examinations were evaluated, carried out in 2012, belonging to the archives of the Dental Radiodiagnosis Institute located in the city of Campinas, São Paulo. A total of 86 exams were selected, comprising patients of both sexes, aged between 20 and 81, with teeth in both arches and endodontically treated teeth, presenting with just one apical periodontitis. The following cases were excluded: exams conducted prior to 2012 and patients with poor facial development, edentulous and a history of tooth fractures or periradicular surgery, and other pathologies not of endodontic origin.

All the exams were acquired using the $\mathrm{i}-\mathrm{CA} \mathrm{T}^{\circledR} \mathrm{Classic}$ system (Imaging Sciences, Hatfield, PA, USA), with a voxel of $0.25 \mathrm{~mm}$, FOV of $13 \mathrm{~cm}$ and acquisition time of 40 seconds. The factors applied were as follows: $120 \mathrm{kV}$ fixed and a variation of 5 to $7 \mathrm{~mA}$ according to the resolution employed.

The images were evaluated on an LCD flat-screen 17" monitor (LG 5000:1), at a resolution of $1280 \times 1024$ pixels and maximum color quality (12 bits), and using the software application XoranCAT $^{\circledR}$, version 3.1.62 (Xoran Technologies, Ann Arbor, MI, USA), using tools to adjust brilliance and contrast and also the application of an AngioSharpen-Low $3 \times 3$ image filter in order to standardize and support AP identification.

All the analyses and measurements were carried out by a single examiner, a radiology specialist with experience in tomographic images. Based on a multiplanar reconstruction (MPR), $1 \mathrm{~mm}$ thick cross-sectional slices were formed perpendicular to the alveolar ridge (Figure 1).

After selecting the images, two groups were formed, one for apical periodontitis in the lower teeth and one for the upper teeth. Subsequently, the cross-sectional slice was measured using a purpose-specific tool from the apex to the farthest extent of the lesion, classifying it according to the periapical index scores proposed by Estrela et al.27, as described in Table 1, however the growth and/or destruction of the bone cortex was not taken into account.

The descriptive analysis was carried out at a level of significance of $5 \%$, using the software application Minitab Release14 (Minitab Inc. International, State College, PA, USA). 
Table 1. Apical periodontitis scores according to the index proposed by Estrela et al. ${ }^{27}$ for analysis via CBCT.

\begin{tabular}{cc}
\hline Scores & Quantitative bone change \\
\hline 0 & No lesion \\
1 & Diameter of the hypodense periapical area $>0.5 \mathrm{to} 1 \mathrm{~mm}$ \\
3 & Diameter of the hypodense periapical area $>1 \mathrm{to} 2 \mathrm{~mm}$ \\
4 & Diameter of the hypodense periapical area $>2 \mathrm{to} 4 \mathrm{~mm}$ \\
5 & Diameter of the hypodense periapical area $>4$ to $8 \mathrm{~mm}$ \\
$\mathrm{E}$ & Diameter of the hypodense periapical area $>8 \mathrm{~mm}$ \\
$\mathrm{D}$ & Cortical bone growth \\
Cortical bone destruction
\end{tabular}

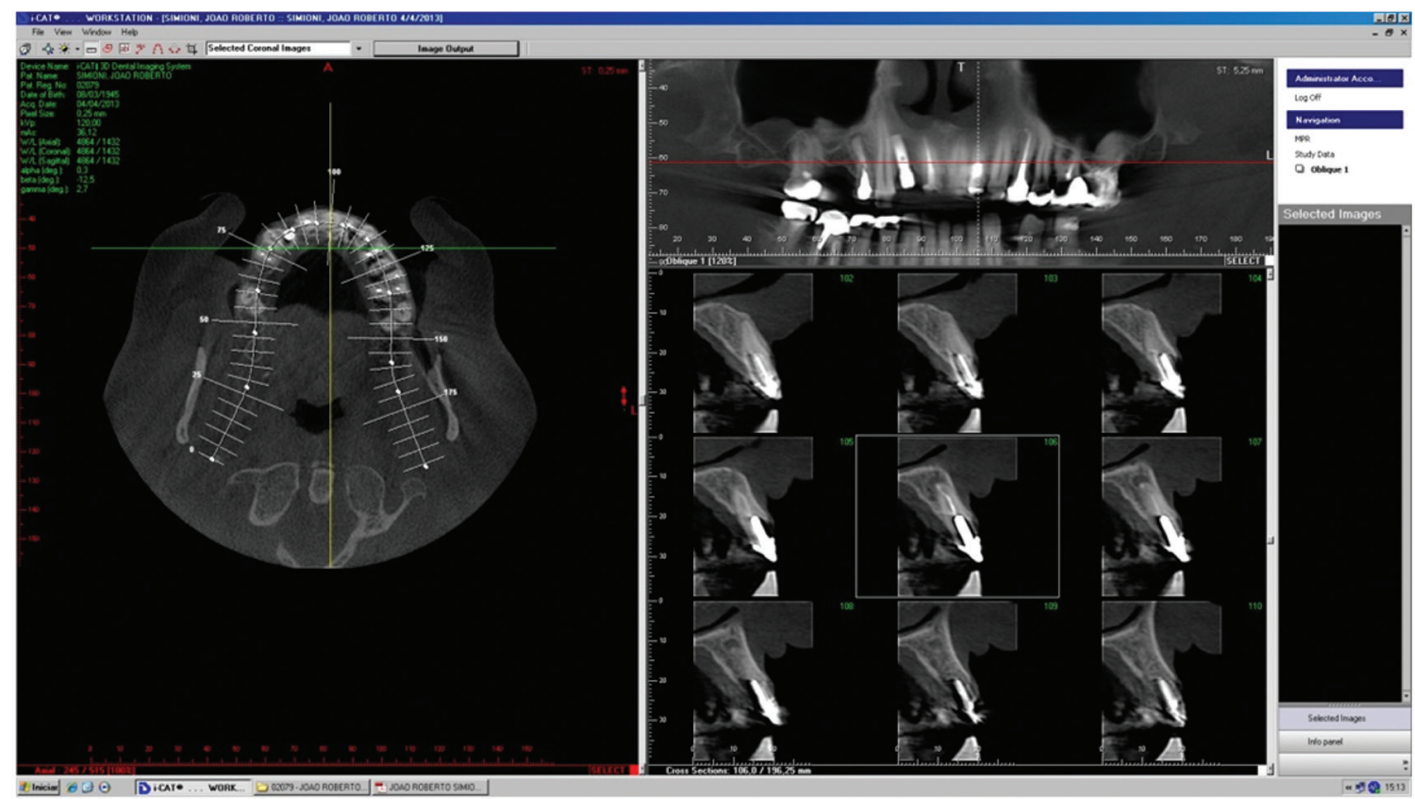

Figure 1. Slice tracking the alveolar ridge, in axial image, in order to obtain the panoramic reconstruction and the cross-sectional slices.

\section{RESULTS}

A descriptive statistical analysis was performed on the absolute $(n)$ and relative (\%) values of the number of teeth and the size, in millimeters, of the apical periodontitis, relating to each lower and upper tooth. The respective results are shown in Tables 2 and 3.

Afterwards, the apical periodontitis score was associated with the arch, giving the absolute (n) and relative (\%) numbers of each score, as shown in Figures 2 and 3.

Table 2. Absolute $(n)$ and relative (\%) values of the number of teeth and size of the apical periodontitis in respect of each tooth in the lower arch

\begin{tabular}{lccccc}
\hline Tooth & Number $(\mathbf{n})$ & Percentage $(\%)$ & Mean $(\mathbf{m m})$ & Standard Deviation & Median \\
\hline 31 & 3 & 2.36 & 0.17 & 0.29 & 0 \\
32 & 3 & 2.36 & 0.26 & 0.46 & 0 \\
33 & 10 & 7.87 & 0.39 & 0.53 & 0 \\
34 & 16 & 12.60 & 0.19 & 0.42 & 0 \\
35 & 18 & 14.17 & 0.43 & 0.49 & 0.25 \\
36 & 11 & 8.66 & 0.62 & 1.01 & 0 \\
\hline
\end{tabular}


Table 2. Continued.

\begin{tabular}{lccccc}
\hline Tooth & Number $(\mathbf{n})$ & Percentage $(\%)$ & Mean $(\mathbf{m m})$ & Standard Deviation & Median \\
\hline 37 & 5 & 3.94 & 0.78 & 0.94 & 0.70 \\
41 & 3 & 2.36 & 0.30 & 0.28 \\
42 & 2 & 1.57 & 0.16 & 0.22 & 0.35 \\
43 & 3 & 2.36 & 0.19 & 0.32 & 0.75 \\
44 & 14 & 11.02 & 0.50 & 0.26 & 0.53 \\
45 & 16 & 12.60 & 0.90 & 0.52 & 0.75 \\
46 & 8 & 6.30 & 0.62 & 0.35 \\
TOTAL & 11 & 8.66 & 0.49 & 0.75 \\
\hline
\end{tabular}

Table 3. Absolute (n) and relative (\%) values of the number of teeth and size of the apical periodontitis in respect of each tooth in the upper arch.

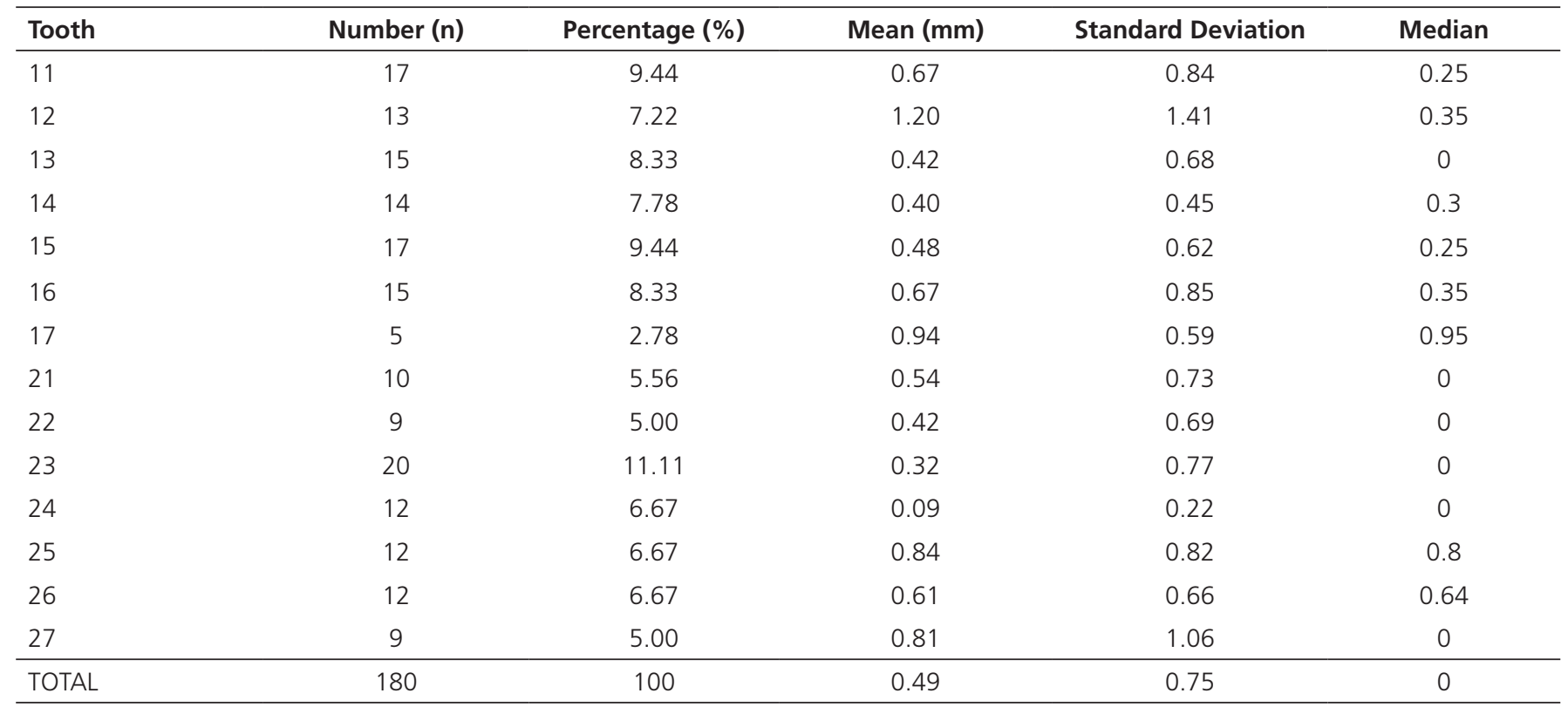

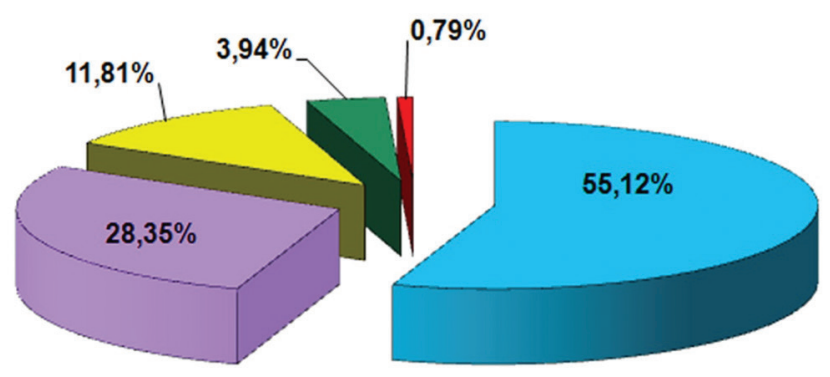

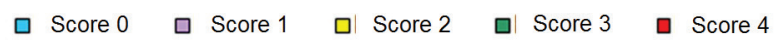

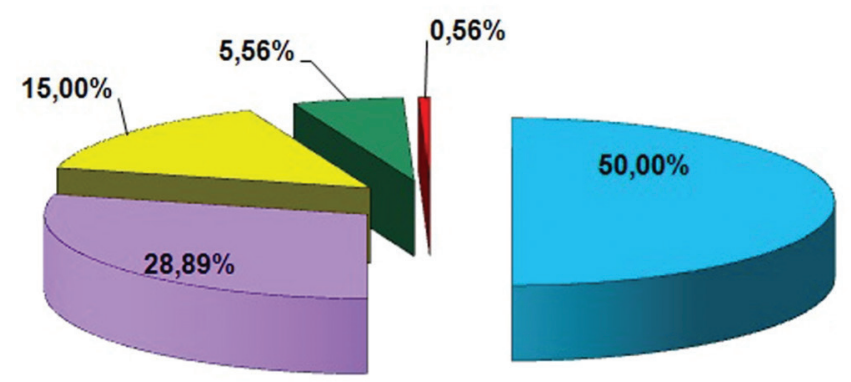

$\square$ Score 0

$\square$ Score 1

ㅁ Score 2

Score 3

S Score 4
Figure 2. Graphical representation of the frequency of scores in the lower teeth. Scores are identified according to the colors in the caption.
Figure 3. Graphical representation of the frequency of scores in the upper teeth. Scores are identified according to the colors in the caption. 


\section{DISCUSSION}

The ability to detect an apical periodontitis radiographically depends, amongst other factors, on the location of the lesion inside the bone. The lesion is more easily viewed radiographically when it is close to or in the cortical region and least likely to be seen when it is in the region of the spongy bone. The images selected in the study were reconstructed without the superimposition of the cortical block, showing what is really happening inside the spongy bone and the reconstructed slice was directed so as to result in orthogonal slices viewed parallel and perpendicular to the longitudinal axis of the root under investigation. These factors resulted in a greater perception of the number of roots, canals and instances of apical periodontitis present in the tooth ${ }^{28-29}$.

From a sample consisting of 86 examinations, a total of 127 lower teeth and 180 upper teeth were observed with apical periodontitis (AP).

The lesions were measured ignoring the growth and/or destruction of the cortical bone and, in general, it was found that the lesions identified had an average size of $0.49 \mathrm{~mm}$ in the mandible and $0.75 \mathrm{~mm}$ in the maxilla. The lower premolars were the teeth most afflicted by $A P$, with an average size of $0.19 \mathrm{~mm}$ (tooth 34) and $0.43 \mathrm{~mm}$ (tooth 35), $0.50 \mathrm{~mm}$ (tooth 44) and $0.90 \mathrm{~mm}$ (tooth 45). As the roots of these teeth are close to anatomical structures such as the mental foramen and the mandibular canal, there is always the possibility of damage to the nerves in the presence of large lesions. When AP is associated with the upper canines, premolars or molars, it could trigger an inflammatory response within the adjacent maxillary sinus, resulting in thickening of the sinus mucosa, periostitis and sinusitis ${ }^{1,8}$.

The AP measurements were taken using a purpose-specific tool from the apex to the farthest point of the lesion, and based on these values they were classified as shown in table 1, unlike the study by Garcia de Paula-Silva et al. ${ }^{4}$ where the volume was recorded in cubic millimeters. A system was used with scores identified using numbers from 0 to 5 , the CBCTPAl index, and when the tomographic images of the AP were analyzed, the predominant score was in the range 0 to $0.50 \mathrm{~mm}$, in both jaws, and $55.12 \%$ of endodontically treated lower teeth and $50 \%$ upper teeth showed no recurrence of lesion nor lesions in the process of repair. Lesions identified with scores between 0 and 1 corresponded to $83.47 \%$ of lesions in the mandibular and $78.89 \%$ in the maxilla, confirming the indication of CBCT for identifying AP of small dimensions ${ }^{2-3}$.

A single examiner analyzed all the tomographic images due to the absence of subjectivity in the CBCT-PAI periapical index and to the specific nature of cone beam CT which permits the reproduction of images identical to the object in a 1:1 spatial ratio. In a number of clinical studies $^{2,16-17}$, one to three observers analyzed the CBCT images and found that there was no significant difference between intra- and inter-observer measurements.

By grouping all the AP identified in this study, ranging from small-diameter lesions to those seen through conventional exams, scores between 1 and 4, it was possible to observe that for the mandible, CBCT accuracy reaches $44.88 \%$ and for the maxilla it is $50 \%$, demonstrating the efficiency of this imaging method.

Early detection of AP is an important step to evaluating the efficiency of the treatment, however early detection is complicated as changes are usually subtle and not particularly significant. CBCT may be recommended for detecting AP where there is some clinical suspicion though not identified in periapical radiographs ${ }^{17}$. This study did not monitor the history, evolution and healing of the AP nor was any histological evaluation conducted, these being the limitations of the study when compared to the studies of Garcia de Paula-Silva et al. ${ }^{4}$, Wu et al. ${ }^{23}$ and Jorge et al. ${ }^{30}$

$C B C T$ is an important instrument, both for the identification of small-dimension AP and the evaluation of endodontic success, therefore further studies should be carried out with regard to their characteristics, such as radiographic density and healing time.

\section{CONCLUSION}

Considering the results obtained in the present study, it may be concluded that there was a predominance of small apical periodontitis, the premolars being the most affected.

\section{Collaborators}

LCT MORETI was responsible for the study and took part in the composition of the article. FK PANZARELLA took part in the data collection and analysis as well as the composition of the article. M OLIVEIRA was responsible for image selection and took part in the composition of the article. JLC JUNQUEIRA was responsible for the 
acquisition of the tomographic images and participated in the composition of the article. LRC MANHÃES JUNIOR

\section{REFERENCES}

1. Lofthag-Hansen S, Huumonen S, Gröndahl K, Gröndahl H-G. Limited cone-beam CT and intraoral radiography for the diagnosis of periapical pathology. Oral Surg Oral Med Oral Pathol Radiol Endod. 2007;103(1):114-9. doi: 10.1016/j. tripleo.2006.01.001

2. Estrela C, Bueno MR, Leles CR, Azevedo B, Azevedo JR. Accuracy of cone beam computed tomography and panoramic and periapical radiography for detection of apical periodontitis. J Endod. 2008;34(3):273-9. doi: 10.1016/j.joen.2007.11.023

3. Patel S, Dawood A, Mannocci F, Wilson R, Pitt Ford T. Detection of periapical bone defects in human jaws using cone beam computed tomography and intraoral radiography. Int Endod J. 2009;42(6):507-15. doi: 10.1111/j.1365-2591.2008.01538.x

4. Garcia de Paula-Silva FW, Hassan B, Bezerra da Silva LA, Leonardo MR, Wu MK. Outcome of root canal treatment in dogs determined by periapical radiography and cone-beam computed tomography scans. J Endod. 2009;35(5):723-6. doi: 10.1016/j.joen.2009.01.023

5. van Assche N, Jacobs R, Coucke W, van Steenberghe D, Quirynen $M$. Radiographic detection of artificial intra-bony defects in the edentulous area. Clin Oral Implants Res. 2009;20(3):273-9. doi: 10.1111/j.1600-0501.2008.01576.x

6. Scarfe WC, Levin MD, Gane D, Farman AG. Use of cone beam computed tomography in endodontics. Int J Dent. 2009;2009:634567. doi: 10.1155/2009/634567

7. Tetradis S, Anstey P, Graff-Radford S. Cone Beam Computed Tomography in the diagnosis of dental disease. J Calif Dent Assoc. 2010;38(1):27-32.

8. Cotton TP, Geisler TM, Holden DT, Schwartz SA, Schindler WG Endodontic applications of cone-beam volumetric tomography. J Endod. 2007;33(9):1121-32. doi: 10.1016/j.joen.2007.06.011.

9. Stavropoulos A, Wenzel A. Accuracy of cone beam dental $\mathrm{CT}$, intraoral digital and conventional film radiography for the detection of periapical lesions. An ex vivo in pig jaws. Clin Oral Investing. 2007;11(1):101-6. doi: 10.1007/s00784-006-0078-8

10. Low KMT, Dula K, Burgin W, Arx T von. Comparison of periapical radiography and limited cone-beam tomography in posterior maxillary teeth referred for apical surgery. J Endod. 2008;34(5):557-62. doi: 10.1016/j.joen.2008.02.022

11. SoğurE, Baksi BG, Grondahl H-G, Lomcali G, Sem BH. Detectability of chemically induced periapical lesions by limited cone beam computed tomography, intra-oral digital and conventional film radiography. Dentomaxillofac Radiol. 2009;38(7):458-64. doi: $10.1259 / \mathrm{dmfr} / 15206149$

12. Ozen T, Kamburoglu K, Cebeci ARI, Yüksel SP, Paksoy CS Interpretation of chemically created periapical lesion using 2 different dental cone-beam computerized tomography units, an intraoral digital sensor, and conventional film. Oral Surg Oral directed the study and took part in the composition of the article.

Med Oral Pathol Oral Radiol Endod. 2009;107(3):426-32. doi: 10.1016/j.tripleo.2008.08.017

13. Estrela $C$, Bueno $M R$, Porto $O C L$, Rodrigues $C D$, Pécora JD Influence of intracanal post apical periodontitis identified by cone-beam computed tomography. Braz Dent J. 2009;20(5):3705. doi: 10.1590/S0103-64402009000500003

14. Christiansen R, Kirkevang LL, Gotfredsen E, Wenzel A Periapical radiography and cone beam computed tomography for assessment of the periapical bone defect 1 week and 12 months after root-end resection. Dentomaxillofac Radiol. 2009;38(8):531-6. doi: 10.1259/dmfr/63019695

15. Moura MS, Guedes AO, Alencar AH, Azevedo BC, Estrela C. Influence of length of root canal obturation on apical periodontitis detected by periapical radiography and cone beam computed tomography. J Endod. 2009;35(6):805-9. doi: 10.1016/j.joen.2009.03.013

16. Kamburoglu K, Kiliç C, Ozen T, Horasan S. Accuracy of chemically created periapical lesion measurements using limited cone beam computed tomography. Dentomaxillofac Radiol. 2010;39(2):959. doi: $10.1259 / \mathrm{dmfr} / 85088069$

17. Soğur E, Gröndahl HG, Baksı BG, Mert A. Does a combination of two radiographs increase accuracy in detecting acid-induced periapical lesions and does it approach the accuracy of cone-beam computed tomography scanning? J Endod. 2012;38(2):131-6. doi: 10.1016/j.joen.2011.10.013

18. Paes da Silva Ramos Fernandes LM, Ordinola-Zapata $R$ Húngaro-Duarte MA, Álvares Capelozza AL. Prevalence of apical periodontitis in cone beam CT images of a Brasilian subpopulation. Dentomaxillofac Radiol. 2013;42(1):80179163. doi: 10.1259/dmfr/80179163

19. Chevigny C, Dao TT, Basrani BR, Marquis V, Farzaneh M, Abitbol $S$, et al. Treatment outcome in endodontics: the Toronto study-phase 4: initial treatment. J Endod. 2008;34(3):258-63. doi: 10.1016/j.joen.2007.10.017

20. Ioannidis $K$, Thomaidis $V$, Fiska $A$, Lambrianidis $T$. Lack of periradicular healing and gradually increasing swelling two years after intentional extrusion of calcium hydroxide into periapical lesion: report of a case. Oral Surg Oral Med Oral Pathol Oral Radiol Endod. 2010;109(6):e86-91. doi: 10.1016/j.tripleo.2010.02.006

21. Huumonem S, Kvist T, Grondahl K, Molander A. Diagnostic value of computed tomography in re-treatment of root fillings in maxillary molars. Int Endod J. 2006;39(10):827-33. doi: 10.1111/j.1365-2591.2006.01157.x

22. Torabinejad M, Corr R, Handysides R, Shabahang S. Outcomes of nonsurgical retreatment and endodontic surgery: a systematic review. J Endod. 2009;35(7):930. doi: 10.1016/j. joen.2009.04.023.7

23. Wu M-K, Shemesh $H$, Wesselink PR. Limitations of previously published systematic reviews evaluating the outcome of endodontic treatment. Int Endod J. 2009;42(8):656-66. doi: 10.1111/j.1365-2591.2009.01600.x 
24. Orstavik D. Radiographic evaluation of apical periodontics and endodontic treatment results: a computer approach. Int Dent J. 1991;41(2):89-98

25. Kaffe I, Gratt BM. Variations in the radiographic interpretation of the periapical dental region. J Endod. 1988;14(7):330-5. doi: 10.1016/S0099-2399(88)80193-6

26. Nurbakhsh B, Friedman S, Kulkarni GV, Basrani B, Lam E. Resolution of maxillary sinus mucositis after endodontic treatment of maxillary teeth with apical periodontitis: a cone-beam computed tomography pilot study. J Endod. 2011;37(11):150411. doi: 10.1016/j.joen.2011.07.007

27. Estrela C, Bueno MR, Azevedo BC, Azevedo JR, Pecora JD. A new Periapical Index based on cone beam computed tomography. J Endod. 2008;34(11):1325-31. doi: 10.1016/j.joen.2008.08.013

28. Blattner A, George N, Lee CC, Kumar V, Yelton CD. Efficacy of cone-beam computed tomography as a modality to accurately identify the presence of second mesiobuccal canals in maxillary first and second molars: a pilot study. J Endod. 2010;36(5):86770. doi: 10.1016/j.joen.2009.12.023

29. Matherne RP, Angelopoulos C, Kulild JC, Tira D. Use of conebeam computed tomography to identify root canal systems in vitro. J Endod. 2008;34(1):87-9. doi: 10.1016/j.joen.2007.10.016

30. Jorge EG, Tanomaru-Filho M, Gonçalves M, Tanomaru JM. Detection of periapical lesion development by conventional radiography or computed tomography. Oral Surg Oral Med Oral Pathol Oral Radiol Endod. 2008;106(1):e56-61. doi: 10.1016/j. tripleo.2008.03.020

Received on: 18/5/2015

Final version resubmitted on: 4/12/2015

Approved on: 15/12/2015 